\title{
Por Um Modo Mais Incorporado de Explicar o Fazer do Psicólogo
}

For a More Integrated Way of Explaining How a Psychologist Works

Por Un Modo Más Incorporado de Explicar el Hacer del Psicólogo

Etiane Araldi, Cleci

Maraschin

\& Rafael Diehl

Universidade Federal do Rio Grande do Sul

http://dx.doi.org/10.1590/1982-3703000292013

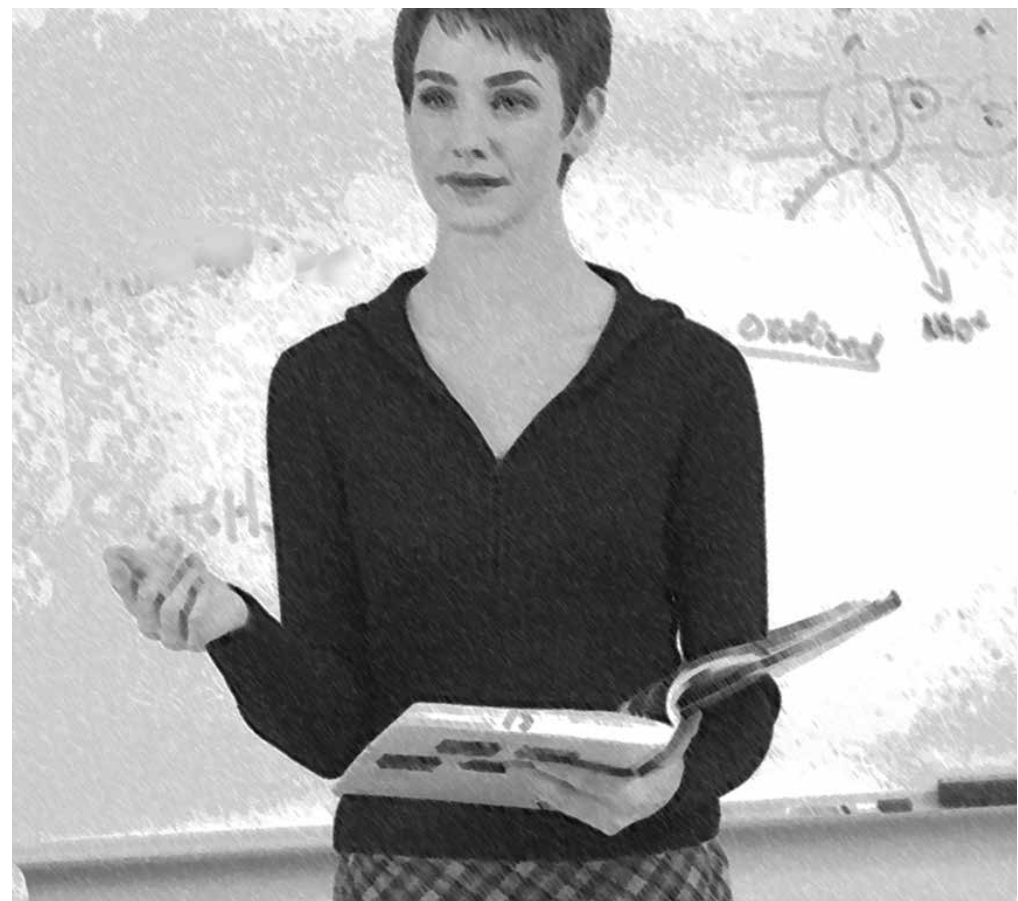


Resumo: O artigo segue as peculiaridades que a chamada "relação teoria-prática" tem assumido na Psicologia, buscando nela pistas para mapear o modo como o problema do conhecer e do conhecimento tem sido colocado nesse campo. São guias nesse trabalho as distinções que estudantes da graduação em Psicologia da Universidade Federal do Rio Grande do Sul (UFRGS) fazem em sua experiência de formação, produzidas em um dispositivo de pesquisa realizado com alunos em estágio de ênfase. Observou-se que os dilemas e impasses distinguidos pelos estudantes têm relação com a colocação do problema do conhecimento psi segundo a teoria do espectador do conhecimento, tal como caracterizada por John Dewey. Uma releitura dessa noção a partir de autores contemporâneos da cognição - principalmente Humberto Maturana, Francisco Varela e Pierre Lévy - é utilizada para recolocar o problema da relação entre teoria e prática na Psicologia. Conclui que o plano concreto do fazer psi não tem sido considerado pelo discurso que situa na teoria o fundamento para o conhecimento do psicólogo.

Palavras-chave: Formação do psicólogo. Relação teoria-prática. Cognição. Conhecimento.

Abstract: The article follows the peculiarities that the so-called "theory and practice relationship" has undertaken in psychology, seeking clues in it to map how the problem of learning and knowledge has been placed in this field. Leading this work are the distinctions that graduate students in psychology at the Federal University of Rio Grande do Sul (UFRGS) make in their training experience, produced in a research device conducted with students on the emphasis stage. We observed that the dilemmas and impasses distinguished by the students relate to placing the problem of psi knowledge under spectator theory of knowledge, as characterized by John Dewey. A rereading of this notion from contemporary cognition authors - especially Humberto Maturana, Francisco Varela and Pierre Lévy - is used to relocate the problem of the relationship between theory and practice in psychology. I concluded that the concrete base for making psi has not been considered by the speech that places in theory the foundation for psychologist knowledge.

Keywords: Psychology formation. Theory and practice relationship. Cognitive. Knowledge.

Resumen: El artículo sigue las peculiaridades que la llamada "relación teoría-práctica" ha asumido en la psicología, buscando en ella pistas para entender el modo como el problema del conocer y del conocimiento ha sido puesto en ese campo. Son guías en este trabajo las distinciones que estudiantes de la graduación en psicología de la Universidad Federal de Río de Grande del Sur (UFRGS) realizan en su experiencia de formación, producidas en un dispositivo de investigación llevado a cabo con alumnos en etapa de énfasis. Se ha observado que los dilemas e impases distinguidos por los estudiantes tienen relación con la presentación del problema del conocimiento psi según la teoría del espectador del conocimiento, tal como caracterizada por John Dewey. Una relectura de esa noción a partir de autores contemporáneos de la cognición - principalmente Humberto Maturana, Francisco Varela y Pierre Lévy - es utilizada para presentar nuevamente el problema de la relación entre teoría y práctica en la psicología. Concluye que el plan concreto del hacer psi no ha sido considerado por el discurso que ubica en la teoría el fundamento para el conocimiento del psicólogo.

Palabras clave: Formación del psicólogo. Relación teoría-práctica. Cognición. Conocimiento.

Um grupo de estudantes de graduação em Psicologia da Universidade Federal do Rio Grande do Sul (UFRGS) conversando sobre o fazer psi:

Regina $^{1}:$ (...) A gente trabalha muito em nível de opinião também, do que parece certo, o que soa como cabível ou não pra situação (...) só que aí tu também parte de uma opinião, se tu problematiza tua prática, é porque tu tem uma opinião sobre isso... E eu acho que isso diferencia a Psicologia enquanto área de atuação de outras, assim, né... Porque a tua... não sei se é bem a tua opinião, mas o teu posicionamento vai direcionar tua prática, o que pode não acontecer, por exemplo, se tu tá inserido num sistema de computação que tu vai seguir um protocolo, sabe? Claro que na Psicologia não é livre, mas tu tem um atravessamento muito forte de ti, assim.

Etiane: Tá, mas olha só, será que é só pensamento, tipo, o que eu penso que vai direcionar minha prática? Como é que é isso, como é que existe essa passagem?

Flávio: Não, mas eu acho que não é o pensar, é o que eu percebo (...) é, porque se tu tem uma percepção do mundo, das coisas que acontecem, e aí faz parte do trabalho tu questionar a percepção que tu teve, é tu fazer um trabalho racional sobre aquilo que tá dado, porque o que tu percebe já tava dado, assim, né... Eu olho pra essa sala e eu vejo o que tá aqui, na minha forma de ver... E depois tem o trabalho racional de pensar sobre aquilo que tá acontecendo que eu tô vendo... 
mestrado, a autora foi bolsista CAPES/

PROF.

3 Com a reforma curricular, segundo as Diretrizes Curriculares

Nacionais para os cursos de graduação em Psicologia (MEC, 2004), se instituiu um estágio básico, a partir do quinto semestre, e os estágios específicos relativos às

ênfases do curso, que, no Instituto de Psicologia

da UFRGS, são as seguintes:

Desenvolvimento Humano: Avaliação, Prevenção e Intervenção; Processos Clínicos: Psicanálise e

Psicopatologia; Psicologia Social e Políticas Públicas.

\section{(...)}

Flávio: (...) Mas eu acho que não é o pensamento pensamento... Eu acho que o pensamento ele tenta refletir um pouco daquilo que tu faz ou pensa ou sei lá o quê, assim... Mas não é, entende... Tu não pensa antes de fazer ou de ver as coisas como tu vê, né... Fazer as leituras é uma coisa meio assim, né... O mundo está contido na tua percepção, na forma como tu vê... E aí dependendo de como tu percebe, tu cria uma racionalização em cima para tentar desconstruir aquilo que tu percebe... E aí esse é o momento de tu fazer uma análise de implicação, por exemplo, de tu estar pensando como tu tá te colocando nos espaços, como tu tá pensando aquilo que tu... E aí isso gera uma retroalimentação, e esse é o...

\section{Etiane: ruminar...}

Flávio: É, que às vezes fica só no ruminar mesmo, porque a gente critica tanto que às vezes não consegue nem analisar o que tu pode fazer para agir sobre a realidade, agir no sentido de externalizar aquilo que te... A leitura que tu fez, assim... Isso também é... Pensar também é agir, né! Mas a questão é tu gerar uma transformação...

Regina: E agir também é pensar...

Flávio: É. Reflete um pensamento, uma forma de ver as coisas, sei lá

Fenix: Claro, é uma ação, né... Parar pra pensar é importante antes de externalizar qualquer coisa, mas de qualquer forma é importante externalizar

Flávio: E parar pra pensar também é agir, de alguma forma...

Fenix: É, foi o que eu disse (risos) Acho que eu não fui clara.

Flávio: É que ela tava ruminando enquanto tu...

Regina: É, eu tava ruminando! (risos) (Grupo 1, terceiro encontro, em 20/06/2011) [grifos nossos].

Essa conversa se deu no interior de um dispositivo de pesquisa ${ }^{2}$ formulado com o intuito de colocar em cena o trabalho real da formação de psicólogos. A expressão trabalho real é utilizada aqui em analogia com os conceitos clássicos da ergonomia de trabalho prescrito e real, e, também, com o sentido de afirmar que há um trabalho, um fazer, também no campo da educação no ensino superior. Fazemos essa afirmação porque nem sempre ela é óbvia. Na pesquisa realizada com os estudantes, não raro se identificava a universidade ao plano do pensamento e os estágios, ao plano da ação. Sim, tampouco se considerava que os estágios eram parte da universidade, tamanha a distância que parece haver entre um mundo e outro, entre os chamados mundos da teoria e da prática. A referida conversa dos estudantes é bastante expressiva no sentido de, ao mesmo tempo, produzir e diluir a diferença entre o pensar e o agir.

Como modo de exploração disso que denominamos como o trabalho real da formação psi, convidamos estudantes da graduação em Psicologia da UFRGS em estágio de ênfase ${ }^{3}$ que desejaram participar da pesquisa para que descrevessem o que faziam nas diferentes práticas de formação - de estudos, pesquisa, extensão, estágios - escrevendo sobre elas entre um encontro e outro com a pesquisadora Etiane Araldi. Oito estudantes aceitaram o convite. Para atender à disponibilidade dos mesmos, foram formados dois grupos, um com cinco pessoas (grupo 1) e outro com três (grupo 2). Houve quatro encontros com cada grupo, nos quais foram discutidos os escritos e as experiências. Os encontros foram gravados e, posteriormente, transcritos para a análise.

O dispositivo metodológico assim formulado inspirou-se nas discussões em torno das metodologias de primeira pessoa (Varela \& Shear, 1999; Depraz, Varela \& Vermersch, 2003) e da pesquisa-intervenção (Maraschin, 2004; Rocha \& Aguiar, 2003). As primeiras foram desenvolvidas no campo da cognição 
com a finalidade de estudo da experiência consciente e orientaram-nos na criação de um método de pesquisa que produzisse, por meio de uma pragmática, uma experiência dos sujeitos com relação a si mesmos e às suas ações. Já a pesquisa-intervenção entrou como consideração da dimensão de produção e mesmo de criação envolvidos em um fazer como o pesquisar e também da implicação do pesquisador nessa atividade.

Além dos materiais dos encontros, contamos também com textos produzidos por uma turma de supervisão do estágio básico, nos quais os estudantes responderam às seguintes perguntas, lançadas pelo supervisor acadêmico: das aprendizagens no curso de Psicologia, que ferramentas conceituais te foram úteis para intervir e operar transformações na realidade apresentada pelo campo de estágio? E que transformações a realidade do campo de estágio operou sobre as aprendizagens do curso e nas ferramentas conceituais em uso?

Embora inicialmente tivéssemos formulado o dispositivo metodológico da pesquisa em torno das produções escritas dos estudantes, no decorrer dos encontros, a conversa foi ganhando relevância. E nossa análise a posteriori da experiência da pesquisa reconheceu nesse conversar mais potencialidade de explorar o nível do fazer e do trabalho real da formação em Psicologia do que o dispositivo que havíamos pensado inicialmente. Isso porque a escrita pareceu estar associada, para os estudantes, à formalidade dos trabalhos acadêmicos e das teorias, enquanto o bate-papo informal com os colegas foi mencionado, em diferentes momentos, como espaço de liberdade e invenção. Essa distinção entre conversar e escrever aponta para os usos cotidianos da escrita na formação, estando mais atrelada a operações de abstração, fator que possivelmente justifique que ela não tenha sido utilizada na pesquisa com o intuito que pretendíamos: como modo de atenção a experiências concretas e cotidianas.

Com isso, quando nos referirmos a essa experiência de pesquisa, muitas vezes, traremos longos excertos das conversas que aconteceram nos encontros. Apesar de isso dificultar a leitura, é importante mantê-los desse modo, para que não se perca, no relato da pesquisa, o potencial da conversa e do diálogo.

\section{Diga-me tua teoria e eu te direi quem és}

"Na teoria é uma coisa, já na prática...". Esse é um enunciado cotidiano em diferentes situações, contextos, lugares. Ao seguirmos o modo como esse e outros discursos sobre a teoria e sobre a prática são utilizados, encontramos algumas significações possíveis para uma e outra palavra. A teoria, por exemplo, ora aparece como a parte prescrita de um trabalho, aquilo que deve ser feito, como em enunciações "em teoria, é assim", contrastando com a prática, associada ao vivido e àquilo que poderíamos denominar como o trabalho real; ora converte-se em um plano abstrato, "isso é apenas teórico", correspondendo àquilo que não existe concretamente.

No campo das discussões sobre a formação acadêmica profissional, como já dissemos, a prática costuma expressar o plano do trabalho, em oposição ao do estudo. Associase a teoria à universidade e a prática aos estágios, trabalho e profissão. A prática é como é, a teoria é como deveria ser. A prática é real, a teoria, ideal. Dizer "na prática" é quase como dizer: "na realidade" ou "na verdade", ou ainda, "à parte as idealizações teóricas, na prática funciona assim". Mas, sobretudo, o que esses discursos produzem é a ideia de que teoria e prática são coisas, fazeres, registros diferentes. Entretanto, diz- 
4 Na UFRGS, a pergunta costuma ser: "tu é do desenvolvimento, do social ou da psicanálise?", em referência aos três departamentos que compõem o curso: o de Psicologia do Desenvolvimento e da Personalidade, de Psicologia Social e Institucional e de Psicanálise e Psicopatologia. se que deveriam coincidir, aproximarem-se, como preconiza o discurso que trata como problema a "distância entre teoria e prática", em seus mais variados níveis e esferas da vida. Na Psicologia, essa relação (teoria e prática) toma uma forma bastante peculiar. Dada a ambiguidade do objeto e da técnica do psicólogo, somada à divisão do campo entre diferentes Psicologias, cada qual com concepções epistemológicas e metodológicas específicas, acostumou-se a aceitar que a teoria é a prática do psicólogo, sendo os conceitos ferramentas de trabalho e a escolha teórica um passo necessário para que o profissional se constitua enquanto tal e para que suas intervenções sejam legitimamente designadas psi. Por vezes, também se considerará que o próprio psicólogo é a sua teoria, quando esses profissionais acrescentam, aos seus sobrenomes, o dos autores com os quais trabalham: freudiano, piagetiano, foucaultiano. E, não raro, um psicólogo é confrontado com a pergunta: "tá, e você é humanista, psicanalista ou cognitivista?"

Supõe-se, ainda, que as práticas desse profissional só podem ocorrer amparadas por uma teoria. Os pressupostos direcionariam as práticas, não se podendo ser ateórico nessa profissão. Contribui para essa ideia justamente a constatação feita por Regina: no trabalho psi, há um atravessamento muito forte do psicólogo enquanto pessoa, com suas opiniões e crenças, por isso, é preciso ter clareza de seus posicionamentos para poder atuar e espera-se que os pressupostos axiológicos das teorias esclareçam essas posições. Esse é o argumento ético invocado para justificar a necessidade da escolha teórica do psicólogo, além do argumento epistemológico: as teorias possuem diferentes pressupostos, concepções de sujeito, visões de homem e de mundo irreconciliáveis e, logo, não podem ser misturadas em uma mesma prática.
$\mathrm{Na}$ esteira dessa ideia, supõe-se que as práticas de um psicólogo psicanalista, por exemplo, possam ser deduzidas diretamente da teoria psicanalítica, sendo o trabalho do psicólogo em determinada contingência comumente descrito segundo as teorias que supostamente lhe dariam sustentação. Mais ainda, nas discussões sobre Psicologia quando os psicólogos se perguntam pelo seu conhecimento - não raro nos deparamos com debates históricos e epistemológicos, sendo a epistemologia, nesses momentos, entendida como as diferentes correntes teóricas que constituem o campo psi, como se a pergunta pelo conhecimento passasse apenas por aí, pela teoria e pelos pressupostos.

Já comentamos, também, que é bastante aceita a ideia de que o psicólogo utiliza ferramentas conceituais em seu trabalho - a própria pergunta dos supervisores de estágio, na referida produção textual dos alunos do estágio básico, inclui essa expressão. Além disso, o uso de metáforas relacionadas às tecnologias de produção e apreensão de teorias são bastante frequentes na explicação do que se faz em Psicologia. Vimos que Flávio menciona a leitura, prática usada para a aprendizagem de teorias, como fazer psi possível em determinada situação.

Em determinado ponto da conversa, complementamos a frase de Flávio com a palavra "ruminar", remetendo a algo que discutíamos um pouco antes do momento recortado no excerto citado. Flávio falava sobre sua admiração a um colega que agora está na residência e que, apesar da demanda prática ali ser muito forte, ainda conseguia pensar:

a residência é uma coisa que monopoliza muito a questão prática mesmo, de tu ter que produzir, de tu ter que dar conta de uma demanda mesmo, né, e eu admiro isso nele que ele tá conseguindo produzir muito intelectualmente em cima e pensar muito as práticas apesar dessa demanda 
Perguntamos, agora, ao leitor:

o fazer psi é pensar? Ou ainda, será que leríamos os pacientes e grupos da mesma maneira como lemos um livro ou um artigo de psicologia? da residência ser meio forte, em termos de produção (...) parece que ele tem o espaço de pensar muito na prática, como um exercício constante, de estar sempre pensando... Eu acho que é uma coisa que a gente tem que se atentar para não perder. Porque é muito fácil se cronificar... (Flávio, terceiro encontro do Grupo 1, em 20/06/11) [grifos nossos].

Percebemos, no modo como a discussão se encaminhava naquele momento, certa cisão entre os planos do pensar e do fazer, então perguntamos: "pois é, mas qual a diferença entre fazer e pensar? Porque a gente tá trabalhando, implicitamente, que é diferente, né?". Vejamos o que diz Flávio, na sequência:

é que na verdade tem essa coisa assim da ruminação, né... É que quando a gente tá no estágio... Ontem mesmo a gente tava lendo um texto sobre empoderamento, que é um termo muito questionado (fala um pouco sobre empoderamento e saúde pública e cidadania) e eu tava fazendo um trabalho sobre isso, isso ontem, né, daí hoje de manhã eu fui pro estágio e eu tava acompanhando a reunião de equipe, e se tava discutindo um caso... E bom, e aí eu vi várias coisas ali, assim... Coisas que tavam indo contra a ideia de promoção da saúde e empoderamento... (conta o caso) E aí eu fiquei com várias inquietações ali, eu ali estagiário, sentadinho, e minha supervisora não tava ali... E aí depois ela chegou e pontuou algumas coisas assim, né, e aí eu: ah, obrigado! (respirando aliviado) Porque eu fiquei ali na minha, só escutando e pensando... (traz questões sobre o cuidado entendido como favor ou como direito do usuário) Mas daí eu fiquei só ruminando, tu lê as coisas e fica assim, bah... Mas eu fiquei na minha... Então talvez seja um pouco assim essa coisa do pensar e do agir, né... O agir seria quando tu faz conhecer aquilo que tu pensa (Flávio, terceiro encontro do Grupo 1, em 20/06/11) [grifos nossos].

Perguntamos, agora, ao leitor: o fazer psi é pensar? Ou ainda, será que leríamos os pacientes e grupos da mesma maneira como lemos um livro ou um artigo de Psicologia? Já no início do século XX, o filósofo John Dewey questionava o que ele denominou como a teoria do espectador do conhecimento.
Segundo essa concepção, dominante nas sociedades ocidentais, conhecer seria o resultado da observação, por parte de um sujeito, de um objeto fixo e independente do observador, supondo um conhecedor passivo diante de um mundo que lhe é anterior e que não é afetado por seu ato de observar (Dewey, 1929). lan Hacking, em entrevista recente, define a teoria do espectador do conhecimento como "a ideia de que todo o nosso conhecimento a respeito do mundo é obtido através do pensamento e do olhar" (Caliman \& Almeida, 2009, p. 468). Dewey (1929) ainda associará a teoria do espectador do conhecimento a um modelo "fotográfico" de apreensão da realidade.

Parece-nos que, no relato dos estudantes, essa ideia se faz bastante presente. No primeiro excerto, embora Flávio diga à pesquisadora que a questão não é o pensamento e sim, a percepção, o mundo contido na tua percepção, sua fala e a de seus colegas ainda parecem supor a existência de: a) uma realidade, que pode ser vista de diversas maneiras; b) um si relativamente estável do psicólogo; c) um trabalho racional de questionar sua própria percepção, entendido como pensar sobre o que se vê e produzir leituras sobre isso; e d) a possibilidade de externalizá-las ou não. Enfim, o trabalho do psicólogo praticamente é descrito como um trabalho de pensamento ou teórico, no sentido como tradicionalmente o concebemos no ocidente: em oposição ao fazer e enquanto visão de mundo. Além disso, no excerto no qual o estudante traz a questão da ruminação, verifica-se uma atitude literalmente de espectador, uma posição analítica quase passiva: eu fiquei ali na minha, só escutando e pensando.

Já dissemos que o termo visão de homem e de mundo é frequente quando a questão é a escolha teórica do psicólogo. Às vezes, usa-se a ideia de lentes como metáfora: haveria o mundo e diferentes lentes teóricas para vê-lo. Novamente, aqui, o modelo fotográfico de 
5 Utilizamos a expressão

"recolocar o problema" com o sentido trabalhado por Kastrup (1999) em seu trabalho sobre a cognição, enquanto possibilidade de, mais do que solucionar problemas dados, buscar as condições de sua formulação e reformulação. colocação do problema do conhecimento. Comentamos também que a escolha de uma visão de homem e de mundo seria necessária à atuação desse profissional, dada, justamente, aquela questão trazida por Regina de que, na Psicologia, o teu posicionamento vai direcionar tua prática. Ao reconhecerem que há "um atravessamento muito forte de ti" na profissão, psicólogos parecem abrigarem-se em suas teorias para fundamentar suas práticas, evitando que elas estejam apoiadas apenas em suas crenças pessoais, remetendo ao velho medo da Psicologia de ser confundida com o senso comum e não ser reconhecida como prática científica.

Segundo Dewey (1929), a teoria do espectador do conhecimento foi mesmo acompanhada, na epistemologia, pela busca de um fundamento para o conhecimento. Afinal, quando se supõe um sujeito e um mundo prévios à experiência de conhecer, como saber se o conhecimento que se tem do mundo é válido ou não?

Diferentes autores contemporâneos têm retomado a crítica feita por Dewey (1929) e buscado, assim como ele, recolocar o problema do conhecer e do conhecimento ${ }^{5}$ não mais em termos de representação, e, sim, de ação. É o que faz, no campo da cognição, a teoria da enação de Francisco Varela e, sobretudo, a biologia do conhecer de Humberto Maturana, em parte desenvolvida em parceria com Varela.

Como modo de deslocar-se daquilo que Dewey (1929) expressou com sua teoria do espectador do conhecimento, Maturana (1999) proporá a investigação das origens biológicas do observador e do observar. Embora Maturana não faça referência a Dewey em seu trabalho, sua caracterização do "caminho explicativo da objetividade sem parênteses" remete àquilo que Dewey denominou como "teoria do espectador do conhecimento". Segundo Maturana (1999), quando o observador "aceita suas habilidades cognitivas enquanto tais como suas propriedades constitutivas" (p. 248) e não investiga suas origens biológicas, acaba por assumir que "a existência acontece independentemente do que ele ou ela faz, que as coisas existem independentemente de se ele ou ela as conhece" (p. 248).

Contrariamente a esse modo de colocar o problema do conhecer e do conhecimento, Maturana postulará a importância da consideração do observador. Segundo o autor, "já estamos na experiência de observar quando começamos a observar nosso observar" (Maturana, 2001, p. 125). Levar em conta essa recursividade é importante, porque não podemos nos situar em algum lugar fora da nossa experiência para explicála. Mesmo se quisermos explicar algo que esteja supostamente "fora" de nós, essa impossibilidade se impõe, porque só podemos observar a partir da nossa condição de seres humanos. E, segundo Maturana (2001), essa condição é a de seres biológicos imersos na linguagem, a qual impede que acessemos qualquer mundo independente de nossa experiência: "nós já nos encontramos na linguagem, fazendo distinções na linguagem, quando começamos a refletir na linguagem sobre o que fazemos, e como fazemos o que fazemos ao operar como animais linguajantes" (p. 125).

Tanto a biologia do conhecer de Humberto Maturana quanto a teoria da enação de Francisco Varela colocam-se como um contraponto ao cognitivismo computacional - uma das principais vertentes teóricas das ciências cognitivas e também a mais utilizada pela Psicologia cognitiva, por defenderem que a percepção consiste em uma ação incorporada e não em uma representação, ou captura, de um mundo exterior. O problema da teoria cognitivista clássica estaria na distinção entre um sujeito que conhece e 
...surge a ideia de que o mundo é dotado de "informações" que são "representadas" pela cognição, encarnada no cérebro, a partir do mecanismo de input (entrada da informação), processamento (por meio da decodificação da informação em símbolos, segundo regras lógicas), output (saída) (Varela, Thompson \& Rosch, 2003). um mundo que se dá a conhecer. Ao tomar essa suposição como ponto de partida, a tarefa seria decifrar como sujeito e mundo se comunicam, ou seja, como o sujeito percebe o mundo, e como nele age. Assim, surge a ideia de que o mundo é dotado de "informações" que são "representadas" pela cognição, encarnada no cérebro, a partir do mecanismo de input (entrada da informação), processamento (por meio da decodificação da informação em símbolos, segundo regras lógicas), output (saída) (Varela, Thompson \& Rosch, 2003). A diferença desse modelo para o de estímulo-resposta, do behaviorismo, seria a concepção de que o processo se retroalimenta, por meio do mecanismo de feedback (Dupuy, 1996).

De fato, é comum sentirmos que, ao pensar, estamos fazendo representações do mundo e de nossas próprias experiências. No entanto, na maior parte de nossas vidas simplesmente vivemos e não nos parece de forma alguma que estejamos "processando informações". Para o cognitivismo, esse seria um mecanismo não consciente, mas o grande responsável por nossas percepções, pensamentos, ações. Ocuparia, portanto, o lugar de sujeito transcendental em relação às nossas experiências conscientes (sujeito empírico) - fazemos referência aqui ao esquema kantiano, que tem fundamentado a concepção de conhecimento da ciência.

E se o problema estiver mal formulado? E se, ao contrário, não pudéssemos supor um mundo e um sujeito prévios? E se os sujeitos inventassem a si mesmos e ao mundo em sua própria história de experiências de acoplamento estrutural com o meio? Essa é a hipótese de Francisco Varela e Humberto Maturana, segundo a qual, conhecemos com nosso corpo inteiro (e não apenas com nosso cérebro), por meio de nossas ações e da história de nossas ações, sendo as representações efeito dessas perturbações que sofremos em relação às perturbações do meio, mais do que mecanismo explicativo e causal de nossos conhecimentos (Varela, 1994; Varela, Thompson \& Rosch, 2003).

A noção de perturbação, aqui, é chave para compreendermos a diferença da teoria da enação em relação ao cognitivismo computacional: o mundo não nos informa nada, ele nos perturba, e nós, enquanto sistemas vivos que se autoproduzem (autopoiéticos), criamos (conhecemos) com base nessas perturbações, nos domínios cognitivos que compartilhamos. Isso se sustenta em outra consideração da obra de Maturana e Varela: sua teoria dos sistemas vivos, que se diferem das máquinas por terem como única finalidade a produção de si mesmos, a autopoiese (Maturana \& Varela, 2001). Uma implicação dessa teoria que merece ser destacada é a seguinte: como os sistemas vivos não podem, no momento mesmo da experiência, distinguir entre ilusão e percepção, toda conduta correta ou verdadeira só pode ser definida com relação a outras experiências - próprias ou de outros observadores - por meio da linguagem.

Com isso, a crítica epistemológica que acompanha a teoria da enação se dirige à idealização - que Varela (1996) atribui à cultura ocidental moderna - da abstração, da generalização, enfim, da função transcendental (no sentido de ir além das experiências comuns e cotidianas) que supomos como características dos "bons" e "verdadeiros" conhecimentos. Segundo Varela, Thompson e Rosch (2003):

\footnotetext{
é pelo fato da reflexão em nossa cultura ter sido apartada de sua vida corporal que o problema mente-corpo tornou-se um tópico central da reflexão abstrata. (...) A reflexão é tida como sendo estritamente
} 
6 Aqui

é preciso fazer uma ressalva quanto ao uso do termo "representar". Se estamos apontando os problemas do uso da representação como mecanismo explicativo do conhecimento, seria contraditório utilizar essa expressão em nossa escrita, não? Em acordo com a distinção de Varela, Thompson e Rosch (2003), estamos utilizando o termo em seu sentido fraco, ou seja, com o sentido semântico e cotidiano da palavra, o que é diferente do uso da representação em sentido forte, que

"aparece quando generalizamos a noção mais fraca com vistas a construir uma teoria consolidada sobre como a percepção, a linguagem ou a cognição em geral funcionam" (Varela, Thompson \& Rosch, 2003, p.144), tal como faz o cognitivismo. mental, e assim surge o problema de como ela pode estar ligada à vida corporal ( p. 46)

Na descrição de Flávio, vemos o fazer psi ser descrito em termos de racionalização, leitura, ruminação, parecendo que não seria o corpo do psicólogo que estaria presente nas situações de intervenção psi, ao contrário, seria uma mente reflexiva e desincorporada, habitada por suas leituras e conceitos. Essa visão não considera, ainda, os domínios cognitivos e os critérios de validação compartilhados com outros observadores na linguagem. Tudo se passaria como se o conhecimento fosse um produto individual que é incorporado a partir de uma exterioridade teórica/abstrata que fornece "lentes" para ler uma realidade independente.

Para Varela (1996), a idealização da abstração permeia tanto a ciência quanto a filosofia, por isso as ciências cognitivas, em sua vertente mais clássica, o cognitivismo computacional, não teriam abandonado o projeto de descrever o conhecer apenas nesses termos. Considerando a clássica posição de dependência que a Psicologia adota com relação à ciência e à filosofia, o papel historicamente crucial da profissão quanto ao problema da cognição e a marca do dualismo mente-corpo na constituição de seu objeto (Ferreira, 2007), há razões epistemológicas suficientes para pensar que o culto à abstração e à reflexão desincorporada são marcas importantes desse campo. Mas não precisamos recorrer a essa ordem de razões, as experiências de psicólogos em formação são mais interessantes porque, ao mesmo tempo, produzem e interrogam esse modo de representar ${ }^{6} \mathrm{o}$ conhecer e o conhecimento psi:
Flávio: (...) Pensar sobre o que se faz é importante na profissão, mas é penoso... Isso te paralisa às vezes, porque tu vê um monte de questão... E às vezes é como se o sistema tivesse todo armado contra ti. E aí tu fica ali parado, olhando o fluxo acontecer, e tu teria que mudar isso, e tu é o único, assim... Eu sinto muito essa coisa, assim, de que tu tá num entre lugar, num entre lugar, assim, né... E aí eu penso que a graduação em psico é um treino pro neuroticismo, sabe? Essa coisa de ficar ruminando e coisa e tal, um dos traços dos cinco fatores da personalidade, eu tenho a impressão que a gente é treinado a ficar pensando no que tá pensando, e pensando nas coisas que tão acontecendo, e pensando e pensando e pensando... Porque à princípio ter um traço alto de neuroticismo seria uma coisa ruim, né? (risos) Seria patológico assim, não sei... Regina: Por isso que o psicólogo tem que fazer terapia!

Flávio: É, e a gente é treinado para isso assim, né? Porque, tudo que a gente faz, a gente tem que pensar no que que a gente tá fazendo, né? E aí eu acho que tem um treino nesse sentido e isso é, assim, uma coisa... Complicada, né...

Etiane: Por que será que isso é assim? Vocês têm alguma hipótese de por que isso de pensar sobre o que se faz constitui tanto a nossa profissão?

Flávio: Eu acho que todo mundo pensa muito, o diferencial da nossa área é que a gente pensa sobre a gente, a gente pensa sobre o humano... A gente pensa no ponto onde a gente deveria estar sentindo...

Fenix: Sobre a constituição do próprio pensamento e da própria emoção.

Flávio: A gente pensa na hora que a gente deveria estar só sendo, entendeu? A gente fica pensando sobre essa meta coisa, essa meta... Meta coisa, meta cognição que acho que é o complicado...

(...)

Fenix: O que tu pensa influencia tua prática tua visão de mundo, teoria, enfim... Mas eu acho que às vezes também isso tem outras relações... A instituição, a organização que tu tá ou o tempo que tu tá naquele serviço ou o quanto tu tá conseguindo fazer esse questionamento, esse distanciamento.. É muito fácil entrar na lógica do serviço, 
do que criar outro fazer... (fala um pouco da distância entre as leituras sobre o SUS, Psicologia social e realidade dos serviços) (...)

Fenix: E acho que aí, sim, há a distância entre o teu pensar e o teu fazer muito grande, e que às vezes te atropela e tu não consegue nem perceber isso ali... E aí quando tu percebe que a tua prática não tem nada a ver com o que tu pensa, tu te sente mal e tu até te culpabiliza... Só que é complicado tu fazer isso, porque daí tu não tem uma visão mais ampla daquilo ali... Ai, é complicado! (suspirando)

Etiane: Por que a culpa?

Roberta: Eu acho que mexe com a autonomia... Será que eu vou conseguir fazer aqui as minhas ideias?

(Grupo 1, terceiro encontro, em 20/06/11) [grifos nossos].

Nos excertos acima, a atitude de espectador do conhecimento do psicólogo começa a sofrer algumas desestabilizações, em relação aos excertos anteriormente citados. Aqui se percebe que ela nem sempre contribui para a intervenção profissional, abrindo a possibilidade de se considerar que o trabalho psi exige uma ação diferente daquela do pensamento analítico e distanciado.

"A gente pensa onde a gente deveria estar sentindo, onde a gente deveria estar só sendo" é uma colocação que expressa o quanto opera, nas representações cotidianas do fazer psi, um pensar desencarnado e desemocionado. É curioso que, no ensino do "profissional das emoções" - mesmo sendo tal processo, a emoção, compreendida em nossa cultura como essencialmente corporal (Despret, 2011) - se produza uma aprendizagem que, em última instância, desconsidera o corpo. Mas, claro, ele é desconsiderado apenas nas representações que fazemos do conhecimento psi (quando dizemos que ele é questão de pensamento), porque o corpo continua ali, sendo treinado para o neuroticismo e a ruminação, como bem expressam os estudantes. Há um treino e uma modificação corporal na formação. A questão é que as experiências dos estudantes denunciam, a nosso ver, um descompasso entre o que incorporaram a partir do fazer acadêmico e o corpo que é demandado nas situações de trabalho psi.

"Será que eu vou conseguir fazer aqui as minhas ideias?" Tal pergunta de Roberta apresenta-se, claramente, como efeito do "modo espectador" de colocação do problema do conhecimento, segundo o qual, primeiro há um ser, que tem ideias, e, depois, as externaliza em ação, sendo essa externalização tomada como a legítima ação do psicólogo: segundo Flávio, "o agir seria quando tu faz conhecer aquilo que tu pensa". Parece relacionar-se também com aquela preocupação ética, que distinguiria a Psicologia de outras profissões, trazida por Regina, a de que "o teu posicionamento vai direcionar tua prática". Com tal visão subjetivista e identitária das ideias e dos posicionamentos, não nos surpreende que a consequência seja a culpa, no sentido mais cristão do termo.

"Será que eu vou conseguir fazer aqui as minhas ideias?" Queremos insistir nessa pergunta, e aqui, como pesquisadores, convém adotar uma posição de observação que não seja a de um observador externo. Reconhecemos essa pergunta como relevante a partir de nossas próprias experiências de formação. Por isso, gostaríamos de somar aos depoimentos dos estudantes um que escrevemos quando esta pesquisa ainda era um projeto:

aceitando o critério epistemológico de validação do conhecimento psi, pareceume importante estabelecer uma coerência em meu modo de pensar e agir, afinado com alguma teoria disponível nos espaços legitimados de formação em Psicologia. Abrigava-me na ideia de que seria melhor adotar a ética compartilhada de uma teoria do que me guiar pela minha própria.

Empenhei-me, a partir de então, em 
7 Usamos

essa expressão em analogia com o procedimento utilizado por Latour (1994) em seu trabalho sobre a modernidade. Sua tese é de que ela não produziu apenas as clássicas dicotomias natureza-cultura, subjetividadeobjetividade, mas também não cessou de produzir híbridos, mistos de humanos e nãohumanos. Contudo, esse trabalho de hibridação não era representado pelo discurso oficial da modernidade, o qual considerava apenas o trabalho de purificação. $\mathrm{O}$ mesmo pode ser dito acerca do conhecimento psi, parece-nos que há uma representação oficial do mesmo que não condiz com o que é, em ação, conhecer Psicologia.

8 Sabemos que a tradução literal de know what é "saber o quê", mas parecenos que a expressão "saber sobre" traduz melhor, em nossa língua, aquilo a que Varela (1996) se refere em sua conceitualização acerca desse modo de conhecer. definir com clareza em que eu acreditava segundo as coerências das diferentes epistemologias que conhecia - fossem elas provenientes de teorias psicológicas, de teorias de áreas afins ou mesmo de textos das políticas públicas de saúde, educação, trabalho. Não foi um exercício fácil, mas aos poucos eu começava a formar algumas ideias sobre o que deveria ser a Psicologia. Contudo, ao iniciar as práticas de estágio, algo me surpreendeu: por mais que eu tivesse muito claro o sentido ético das minhas intervenções, ele não acontecia. Mesmo sabendo o que eu deveria fazer, eu me pegava não conseguindo fazer, ou então fazendo algo que contrariava a ética pressuposta a determinados modos de intervir em Psicologia. Epistemologias que deveriam ser contraditórias de repente pareciam complementares. Pior que isso, eram muitas as situações nas quais já não sabia o que fazer. (Etiane, excerto de depoimento realizado sobre sua experiência de formação incluído no projeto da presente pesquisa).

O texto expressa bem algo que experienciamos como uma diretriz, uma verdadeira prescrição da formação em Psicologia: deveríamos, primeiro, criar para nós uma ideia do que deveria ser a Psicologia, como se fosse bom ter uma espécie de "opinião formada" antes de intervir nos contextos de trabalho psi - a colocação de Regina, no primeiro excerto de conversa dos estudantes trazido neste artigo, dialoga com essa distinção feita em nossa experiência: "se tu problematiza tua prática, é porque tu tem uma opinião sobre isso". E, depois, pensamos que poderíamos implementá-la no estágio, como se pudéssemos ir do plano da teoria ao da prática quase que diretamente. Não foi assim, levando-nos a perguntar onde estaria o problema: em nós, não estaríamos sendo bons o suficiente para conseguir "fazer ali nossas ideias"? Na universidade, que não nos preparou para o mundo do trabalho? Nas teorias, que não estariam adequadas às demandas sociais contemporâneas, sendo necessário criar novas, para darem conta da realidade? Nossa tese, como já mencionamos, é que ele está no modo como comumente representamos o conhecer e o conhecimento psi $^{7}$, pelo menos em espaços universitários de formação, exigindo que o problema seja recolocado nesse nível.

\section{Saber sobre e saber como}

Francisco Varela traz uma distinção que pode nos ajudar a melhor colocar o problema da relação teoria e prática, pensar e fazer, na Psicologia. Basicamente, o autor distingue, retomando termos utilizados por John Dewey no início do século $X X$, conhecimentos do tipo know what e know how. Segundo Varela (1996), os modos de conhecer que se dão pelo julgamento abstrato, por uma espécie de "saber sobre", que se pergunta sobre as coisas (ou mesmo sobre si) e tenta explicá-las por meio de uma atitude reflexiva e racional produzem conhecimentos do tipo "saber o quê" (know what). Contudo, em nossa experiência cotidiana, domina a esfera do "saber como" (know how), ou seja, um conhecimento em ação, corpóreo, vivido e inseparável da história e do contexto que o compõem. No entanto, embora o conhecimento de tipo racional, consciente e intencional (o know what) seja acionado, segundo o autor, apenas em situações nas quais nosso conhecimento de tipo imediato (o know how) falhe, a cultura ocidental convencionou compreender este último como atitudes reflexas, simples, como conhecimento tácito, hierarquicamente inferior ao nosso conhecimento de tipo abstrato e lógico.

Uma passagem de nossos encontros com os estudantes expressa como a distinção entre os planos da teoria e da prática pode coincidir com a diferença entre "saber sobre" ${ }^{8} \mathrm{e}$ "saber como". Em determinada ocasião, um estudante contava aos demais sua observação do saber psi prático que tinham os neurologistas de seu local de estágio, enquanto ele tinha mais o teórico. Ao ser questionado pela pesquisadora sobre qual seria a diferença entre esses dois 
saberes, responde: "pra mim é até bem claro, o saber teórico é aquilo que eu li em algum lugar, e o prático é o que eu precisei sentir na carne, assim" (Agamenon). Continua dizendo que, naquela situação com os neurologistas, também tinha sentido o que eles sentiam, mas, como também já tinha lido sobre aquilo, achava que seu saber era mais claro que o deles, porque tinha lido e tinha visto aquilo acontecer, e eles dificilmente leram sobre:

alguém pode até ter falado pra eles, mais foi um troço meio... Sabedoria oral, assim, sabedoria popular na neurologia. $E$ a diferença entre o meu conhecimento teórico e o prático deles era uma certa informação: o que eles viram em 20, 30 anos de neurologia, eu vi resumido em alguns livros e que eu poderia explicar teoricamente, e certamente os caras poderiam explicar teoricamente também, eles tem estudo, mas possivelmente não com essa mesma clareza que eu... Mas, ao mesmo tempo, eu acho que tem coisas que eles aprenderam na prática e eu não, que eles saberiam identificar com muito mais clareza do que eu, mesmo que eu tivesse lido, porque é aquela coisa do incorporar, tá no organismo isso, eu vejo e já bateu, já sei o que fazer... Não tem muita dúvida. E para mim é algo: eu nunca vi isso na vida, que que eu faço? Ah, mas eu li... Tem que ter um certo piloto automático, acho que essa é a questão (Agamenon, Grupo 2, primeiro encontro, em 09/06/11) [grifos nossos].

$\mathrm{Na}$ fala de Agamenon, parece que a prática tem a ver com esse saber de organismo, automático, incorporado, enquanto o saber teórico é o da explicação, uma espécie de saber depurado e formal que permitiria guiar a ação na prática, ou seja, um "saber sobre" em oposição ao "saber como". No entanto, Varela (1996) defenderá que estamos sempre em um domínio imediato de ação, nunca seríamos capazes de transcender as contingências, mesmo quando estamos em práticas como a reflexão e a teorização. Desse modo, a teoria só poderia ser considerada enquanto prática, embora, é claro, de tipo diferente, se comparada com uma ação de intervenção psi. Mas onde residiria essa diferença? O estudante dá uma pista: o saber teórico é aquilo que eu li em algum lugar e o prático é o que eu precisei sentir na carne.

Se concordarmos com Varela (1996), teremos que discordar que a carne é o que distinguiria o saber prático, já que o teórico também exige um corpo. Contudo, não é por acaso que o estudante associa o corpo ao plano do trabalho psi e a leitura ao teorizar.

Seguindo a linha da teoria da enação, segundo a qual conhecer é agir e não representar, atentaríamos para os diferentes fazeres, incluindo aqui emoções e gestos, que estão em jogo nas atividades de trabalho, estágio, e nas de estudos, leituras e pesquisas em Psicologia. Ou então, perguntaríamos: que corpo é o corpo que faz intervenções psi? E que corpo é o corpo que lê?

O recurso ao trabalho do filósofo da técnica Pierre Lévy, aqui, é importante para elucidar outra faceta dessa questão. Esse autor inscreve as transformações tecnológicas decorrentes do advento da informática na continuidade da história de outras tecnologias que foram, sobretudo, tecnologias da cognição (ou tecnologias da inteligência). Com bastante propriedade, Lévy (1993) mostra como certas formações do pensamento que atribuímos muito facilmente ao plano abstrato das ideias dependeram, em grande medida, de certas tecnologias, objetos concretos, da cultura. É esse o caso de tradições filosóficas como a lógica, o racionalismo e a própria noção de teorias, sobre os quais, embasado em trabalhos de outros autores, Lévy (1993) afirma terem sido possíveis apenas graças à existência de técnicas como a escrita. Essa tecnologia permitiu que experiências passassem a ser comunicadas de modo descolado das contingências de sua produção, por meio dos textos, sendo, por isso, condição 
de possibilidade para processos como a abstração.

E a escrita, por sua vez, só foi encontrada em culturas que já haviam inventado a agricultura, permitindo a hipótese de que teria sido necessária uma determinada relação com o tempo - que concebesse, por exemplo, os tempos da plantação, da espera, da colheita - para que surgisse a escrita como necessidade, sendo ela, também, marcada pelo tempo linear da agricultura. Sem esses acontecimentos, bastante objetivos, teria surgido a História como forma de conhecimento? Possivelmente não.

A partir da análise de exemplos como esse, Lévy lança a questão: "qual a relação entre o pensamento individual, as instituições sociais e as técnicas de comunicação?" (Lévy, 1993, p. 133). Sua proposição é que a inteligência humana seja sempre situada dentro de uma ecologia cognitiva, que agencia sujeitos, instituições e tecnologias.

As considerações do autor levam-nos a atentar, com relação à distinção entre saber prático e saber teórico, para as diferentes tecnologias da inteligência envolvidas em um domínio e outro. No fazer acadêmico e dito teórico, percebe-se fortemente a predominância de técnicas como a leitura, a escrita, que exigem uma atitude mais solitária, introspectiva e, por que não, ruminante. Já no fazer do trabalho psi e dos estágios, os encontros com o outro ganham força, poucas ferramentas concretas entram em jogo, levando a crer que o instrumento do trabalho psi é seu corpo nu e cru. E, de fato, pode-se dizer que é. Mas também existe o outro, as instituições, os quais, curiosamente, são pouco considerados quando o assunto é o problema do conhecer e do conhecimento psi, especialmente quando ele é tratado como questão de teoria e conceitos. Em diferentes momentos, e de diferentes modos, os estudantes trouxeram a percepção da adoção de uma postura analítica e reflexiva que nem sempre os ajudava a intervir nas situações concretas de trabalho, como se pode observar nos dois excertos de diálogo que seguem:

\section{EXCERTO 1:}

Fenix: Eu ia dizer, essa coisa do encontro, que a gente tava dizendo... Porque é muito mais difícil na prática, né? E daí eu fiquei pensando que a gente na formação vê muito, estuda muito e tal, sobre ouvir, né? Sobre ouvir... Sobre como tu escuta aquilo, e um pouco sobre como tu devolve, mas não muito também, né? (risos) Escutar é importante, como tu escuta, como tu interpreta, como tu analisa, como tu relaciona... Tu pode fazer várias coisas com aquilo que tu tá escutando, né? Como tu pergunta, até, né? Pra investigar outras coisas e tal... Mas como que tu vai devolver isso pra pessoa, entendeu? Alguma coisa, alguma coisa, entendeu? A pessoa vai buscando alguma coisa... Não que tu vai dar o que ela tá buscando, porque isso também faz parte do processo terapêutico ali, né e tal, mas... Sabe... Um gesto, assim, mínimas coisas, assim, como é que tu vai falar pra pessoa? Porque às vezes eu me vi, assim, falando e a pessoa dizia: "oi? (risos) tu pode falar, assim, numa língua que eu entenda?". Porque não, porque às vezes a gente começa a falar em demanda e bla bla bla, daqui a pouco sai uns termos técnicos, que tu não percebe, sabe? Ou fala rápido... Eu falo meio embolado assim... Porque tu tá falando para ela um monte de coisa nova, sabe? Diferente pra ela, num palavreado que não é muito o que ela tá acostumada a ouvir... Sabe? Por que a gente não tem uma cadeira de expressão, por exemplo? Expressão corporal, de fala, de devolução, de... Sabe? Psicólogo não pode ser uma múmia, né! Ele tem que ser assim meio socializado, não sei...

Flávio: Essa impressão eu tive muitas vezes: de que eu tava falando uma coisa que não era assim o que a pessoa... Queria, entendia, entendia que era o que ela queria... Essa coisa de tu pressupor um sujeito que é muito... É como se ele soubesse o que tu tá ali pra fazer com ele, entendeu? Tipo, só que ele não sabe... Mas tu imagina que, bom, agora vou falar aqui sobre... 
Fenix: Como é que tu vai transmitir isso? Tá muito mais na tua cabeça do que...

Flávio: É... Tu tá num registro muito diferente, de outras vivências, daí tu quer falar umas coisas que não fazem sentido pra aquela pessoa.

Fenix: Não faz o mínimo sentido...

Flávio: Não faz sentido... Bom, e aí como é que tu faz? Eu queria falar isso, mas não posso falar isso agora, quando que eu posso falar? Como posso falar?

Fenix: Ou como que tu vai chegar nisso...

Flávio: Largo uma letrinha agora e espero, sei lá, seis meses até ele se dar conta sozinho? Como que eu faço?

(Grupo 1, primeiro encontro, em 06/06/11) [grifos nossos].

\section{EXCERTO 2:}

Fenix: Eu acho, também, que o tempo inteiro a gente fica tentando achar o significado... Às vezes não tem, sabe? Não tem!

Regina: Exatamente! Ou tem e a gente não precisa olhar pra ele...

Fenix: A gente tem que tentar parar de analisar o tempo inteiro.

(...)

Regina: É, porque, quando tu tá analisando... Questões grupais, por exemplo, tu tá num outro plano, tu tá vendo de cima... (fala um pouco mais dessa condição de coordenador que tem que ter a visão "ampla", "de cima", mas que também "tá ali dentro") E isso eu acho muito complicado.

Fenix: O problema é que isso ativa um monte de coisas... Quando tu começa a perceber essas nuances... Mas te dá raiva também, sabe? E daí isso é enlouquecedor, porque o que que tu faz com tudo isso, né? Tu sabe o que tá errado, tu sabe identificar, só que... Tá, segunda parte, como é que tu vai... Que que tu faz com isso, entendeu? (...)

Etiane pontua que já haviam trazido essa questão no encontro anterior, quando falavam do devolver.

Fenix: Como tu acessa? Como tu acessa acho que é o difícil...

\section{$(\ldots)$}

Flávio: O que eu acho mais curioso é que não tem muita gente preocupada com isso na Psicologia... Com o acessar... (...) Mas eu não sei distinguir, assim... Acho que pra mim isso é uma grande questão... Descobrir, assim, qual é o alcance da tua intervenção? Porque eu acho que a maior parte das intervenções que a gente faz tende pra essa coisa do entendi, ah, eu entendi... Bom, e quantos entendimentos tu tem que ter pra que um dia tu chegue a um acesso, digamos assim? Que alguma coisa ali opere, que gere uma transformação mesmo, assim... E talvez isso não dependa da nossa prática só, mas do sujeito que tá na tua frente... Mas é, não sei, assim... Não sei avaliar...

(Grupo 1, segundo encontro, em 14/06/11) [grifos nossos]

A sensação de Fenix de que se aprende muito a escutar, analisar, fazer relações, um pouco a perguntar e nada sobre como "devolver" ou sobre o "encontro", somada à discussão trazida por Flávio sobre a ruminação, o "só escutando e pensando", pode denotar, a nosso ver, que o foco do ensino de Psicologia, ao menos na UFRGS, centra-se, sobretudo, no desenvolvimento das habilidades do teórico, enquanto o fazer em jogo nas situações de intervenção psi é um pouco (ou muito) diferente. Ou, ainda, que se forma para o interesse de compreender, mais do que de intervir, possivelmente relacionado à interpretação clássica que fazemos do conhecimento científico como representação da realidade e não como produtor de mundos (lan Hacking citado por Caliman \& Almeida, 2009).

Quando os estudantes usam a metáfora da leitura para explicar suas intervenções nos estágios, também teríamos a incorporação de uma ação tradicionalmente ligada ao fazer teórico e acadêmico sendo transposta, "tacitamente", para o nível que os estudantes denominam como prático, o do trabalho psi. Como se o "saber como" desenvolvido com a prática acadêmica de teorizar fosse levado, 
não sem conflitos, para a de intervir como psicólogo.

Contudo, não deixa de ser interessante que, na ideia de leitura, é como se o corpo fosse esquecido em prol de uma posição abstrata de um sujeito do conhecimento. Assim, poderia se perguntar como uma técnica como a escrita deixou seu caráter de modulação corporal para se tornar uma operação abstrata? Certeau (1994) tem uma discussão interessante sobre o tema, porque critica a suposição de que ler é uma atividade passiva, de "espectador":

numa sociedade sempre mais escrita, organizada pelo poder de modificar as coisas e reformar as estruturas a partir de modelos escritos (científicos, econômicos, políticos), mudada aos poucos em "textos" combinados (administrativos, urbanos, industriais, etc.), pode-se muitas vezes substituir o binômio produção-consumo por seu equivalente e revelador geral, o binômio escrita-leitura. (Certeau, 1994, p. 264)

Ler não é "assimilar". Há um trabalho inventivo do leitor na apropriação dos textos. Contudo, a estética da recepção (Certeau, 1994) vigente com relação à leitura, a ideia de que o leitor é um consumidor, o torna invisível. Infelizmente, em muitos momentos, parece ser a atitude de leitor-espectador que os estudantes transpõem para suas práticas de estágio.

Mas, sobretudo, esse plano dito "das práticas", o das intervenções psi, não tem sido representado pelo discurso acadêmico e sua centralidade da teoria e das "leituras". A conversa com os estudantes naquela ocasião do primeiro excerto parece seguir nesse sentido:

Fenix: Porque tem coisas que tu percebe, e talvez seja importante mesmo, mas naquele contexto... E seja até um direito da pessoa, mas não é uma coisa assim que tu vai dizer na lata, na primeira vez, sabe... Tu não tem vínculo ainda... Mas ninguém te diz isso, na graduação... Ninguém te diz! Tu vai ter que chegar e perceber que tu tá falando um monte de coisa, que tu tá enchendo a pessoa de informação... Daí, depois, que tu sai com uma sensação incômoda, assim, daí tu fica, bah... Talvez eu... Né? Bombardeei ela... (risos) Não devia ter ido por aí...

Flávio: $E$ isso que é o mais engraçado, porque a gente tem esse registro nos textos, tá escrito que o psicólogo vai usar sim a sensibilidade, transferência e contra-transferência e o caramba... E não tem formação nesse sentido... Como a academia pode dar conta disso? Porque isso é vivência, isso é experiência.

Fenix: É, mas por que não pode ter uma cadeira de vivência?

Flávio: Mas devia ter...

Fenix: Com as pessoas, entendeu? Entre o grupo mesmo, a gente vivenciar...

Flávio: Por isso que eu sou uma pessoa que defendo a cadeira de processos grupais... Porque eu acho que ela faz sentido pra mim.

Etiane: Eu fiquei pensando que talvez quando há essa configuração da formação, esse foco na escuta, o foco em fazer relações, análises, mas sem pensar como devolver, se de repente esse tipo de configuração da formação acaba não favorecendo muito o encontro esse...

Flávio: É

Etiane: Não sei, fiquei pensando, assim, que devolver tem a ver... De uma forma, que não venha do além... Numa linguagem ali, pareceria que tu teria que estar mais ali, teria que estar no encontro... Teria que falar desde $o$ encontro...

Fenix: Acho que sim...

Flávio: Tá, mas em teoria até se coloca, não? Tu tem que falar na transferência...

Fenix: É, mas como é que é essa transferência! Não que tu vai ficar numa sala treinando as pessoas, entendeu? Pra... Como falar... Não é isso, sabe, de treinar psicólogos, falas típicas... Entendeu? Mas de... Assim, ó... De poder botar a pessoa na 
suposição desse encontro, entendeu? De promover encontros, de repente antes de tu tá na frente de uma pessoa e não saber o que dizer pra ela, né?

Flávio: Isso eu acho curioso. Porque tem tanto essa ideia da Psicologia, do construtivismo, essa coisa assim mais, né? De poder partir da experiência da pessoa, essa coisa de aprendizagem significativa... Mas acho que na graduação não se pratica isso, né? Porque tem aulas muito expositivas, as vezes, né? Ou tem aulas assim que são dialogadas em cima muito da teoria... Então poderia ser algo assim um pouco mais vinculado com a experiência.

Etiane: Vocês podiam ficar atentos na próxima semana a como é que vocês vão aprendendo isso, porque, mesmo não tendo isso nas aulas, vocês estão aprendendo... Ao invés de como isso poderia ser ensinado, como vocês aprendem?

(Grupo 1, primeiro encontro, em 06/06/11) [grifos nossos].

Chama nossa atenção, nesse último excerto, a ideia de se criar uma "cadeira de expressão". Parece que os estudantes se dão conta da falta desse tipo de aprendizagem no curso, mas, quando thes ocorre incluí-la, o fazem inserindo-a no formato tradicional de aprendizagem da academia: cadeiras, aulas. Seria uma cadeira o melhor formato de aprendizagem da expressão, do devolver e do encontro? Isso anuncia uma cisão muito interessante verificada nos encontros com os estudantes, a de que o estágio não faz parte da graduação. Esta última fica identificada com as aulas, os textos, as teorias, enquanto o estágio como o campo da vivência e da experiência. Nem parece que o estágio faz parte do currículo em colocações como "na graduação não há nada de vivência" ou em outras mais sutis, como a de Fenix que, em certa ocasião, afirmou ter feito um escrito "a partir da prática, do estágio, sem muita reflexão sobre o curso" [grifos nosso]. Se no estágio há vivência e ele faz parte do curso, como não haveria vivência na graduação?
Mas também poderíamos pensar se vivência é a melhor palavra para designar aquilo que parece que se tem mais no estágio. Estudar não seria também uma vivência?

Algo interessante das análises de Lévy (1993) é que elas apontam para a imbricada relação entre os instrumentos utilizados para conhecer e o conhecimento que se tem. O que nos encaminha para supor que esse modo de conhecer analítico e ruminante distinguido pelos estudantes tenha relação com a forte associação entre universidade e cultura escrita. No caso das universidades brasileiras, uma cultura escrita acentuadamente atravessada pela abstração, na forma das teorias importadas e textos que comunicam experiências distantes, os quais marcam o conhecer e o conhecimento universitário em nosso país. Desse modo, talvez seja o nível das ecologias cognitivas e das tecnologias da inteligência aquilo que distingue o que normalmente denominamos como teoria e como prática, e não que uma seja vivencial e a outra não. Ambas supõem uma vivência e uma incorporação, um know how, mas são diferentes os processos corporais e experienciais necessários ao fazer acadêmico - leitura, reflexão, entendimento, explicação - daqueles exigidos no plano do trabalho psi - relações humanas, encontro, "acessar" e "devolver". Nesse nível, sim, de fato, na teoria é uma coisa e, na prática, é outra.

\section{O profissional e o método}

Como vimos nos diálogos acima citados, os estudantes se perguntam pelo "como" das intervenções psi. Como tu acessa, como tu devolve, como? Nós, pesquisadores, também, perguntamos aos estudantes pelo como, como vocês fazem? Justamente porque nos pareceu, em nossas próprias experiências enquanto estagiários de Psicologia, que era disso que a teoria não dava conta. Com a teoria, poderíamos melhor saber o que deveríamos 
fazer, quanto ao como, essa já era outra questão. Justificava-se sua não enunciação no espaço acadêmico porque isso seria fazer uma prescrição técnica e não é disso que se trata o trabalho psi. Mas o mesmo não poderia ser dito acerca das prescrições teóricas?

Em um dos encontros com os estudantes, Arthur começa a falar sobre sua expectativa, no início da graduação, de que encontraria na faculdade prescrições sobre o que fazer, algo do tipo: se isso, então fazer aquilo. Conta que viveu uma crise ao se deparar com um curso que lhe parecia, ao menos nos primeiros anos, um "filosofar no vazio". Mas, depois, quando foi fazer estágio, sentiu que tinha se tornado o próprio instrumento da intervenção, a prática Ihe mostrou isso: na interação com pacientes e com outros profissionais, percebeu que tinha "uma visão diferente e ideias de intervenção absolutamente impensadas pelos outros":

e isso foi coisas que tu foi incorporando durante esse período teórico, vamos dizer assim, tu tava meio que afinando a corda, e daí quando tu vai pra prática tu percebe: pô, eu não tava filosofando no vazio, sabe? Só que eu nunca tinha tentado usar aquilo de alguma maneira" (Arthur, Grupo 2, primeiro encontro, em 09/06/11).

Agamenon, em seguida, conta que sua experiência com seu primeiro paciente foi "meio traumática" (não foi a única vez que ouvimos, na pesquisa, esse relato dos estudantes e podemos dizer que o mesmo se passou em nossa própria "primeira vez"): "quando olhei para o paciente e o paciente olhou para mim, pensei: estudar não adianta nada! Estudar é uma enganação!". Diz que tem medo de olhar o que escreveu naquele prontuário e continua:

A sensação que eu tenho é que nas aulas teóricas a teoria tá fora de ti, é que nem teu time, tu torce por ele, mas ele não é tu, tu é alguém usando a camisa do teu time, daí quando eu ouço o pessoal do terceiro semestre discutindo TCC e psicanálise eu penso: que bobagem! Que coisa primária!
Eu acho essa discussão ridícula, não me serve mais... Aí conforme tu vai atendendo, tu vai incorporando a teoria, ela vai fazendo parte do teu organismo, tu vai virando o... $O$ instrumento da intervenção. E, assim, cada um incorpora o que consegue, o que Ihe é mais adequado (Agamenon, Grupo 2, primeiro encontro, em 09/06/11).

Parece-nos que a constatação de que o psicólogo é o próprio instrumento de seu trabalho pode ser interessante para nos encaminharmos rumo a colocação do problema do conhecer e do conhecimento psi de modo mais incorporado. Contudo, descrever esse corpo profissional como uma teoria incorporada pode reforçar a perspectiva da teoria do espectador do conhecimento.

Se a teoria é uma visão de homem e de mundo, a descrição da técnica do psicólogo em termos de uma incorporação teórica pode supor uma perspectiva mentalista para o conhecer e o conhecimento psi. A nosso ver, tal modo de representá-lo é o que produz alguns mal-entendidos como a sensação que teve Agamenon em suas primeiras experiências de atendimento de que "estudar é uma enganação" ou a de Roberta que se culpa por não conseguir fazer no estágio suas "ideias".

Essas experiências dos estudantes também podem ser efeito da tomada da teoria, na Psicologia, como o trabalho prescrito do psicólogo e não se trata disso. Ela nem sempre é, como os próprios estudantes em outro momento distinguiram, uma "teoria da prática". A descrição de Agamenon e Arthur sobre a incorporação da teoria permite supor que não se a representa apenas como uma incorporação de uma técnica, mas como algo que se daria em nível do ser do psicólogo. 
$\mathrm{Na}$ ocasião de encontro com Arthur e Agamenon, questionamos se a aprendizagem psi seria mesmo questão de incorporação de teoria, como se a teoria do fazer psi pudesse ser anterior à prática, ao que Arthur nos respondeu: "no curso, pelo menos, a teoria vem antes, né?".

\section{Entre teoria e prática, o dispositivo ou a técnica ou o que se faz}

Joana, em texto entregue na supervisão acadêmica sobre sua experiência no estágio básico, escreve:

Essa minha trajetória fez-me pensar na importância de buscar outras experiências de aprendizado dentro e fora da universidade, porque o conteúdo das disciplinas do nosso currículo, pelo menos até o presente momento, não tem esse objetivo de capacitar o aluno com métodos e técnicas de trabalho, o foco tem sido muito mais a introdução a referenciais teóricos, talvez isso seja o básico a que se refere o nosso estágio básico. Porém esse segundo semestre de estágio exigiu-me muito além do básico.

Essa minha experiência de estágio fez-me pensar sobre a importância de cada um em sua trajetória acadêmica construir ferramentas de trabalho, incluindo não só teorias, métodos, técnicas apreendidas nas disciplinas e nos livros. Eu passei a ver o papel do psicólogo como de criação, pois para ser realmente um agente de transformação é necessário extrapolar as ideias já propostas, porque cada contexto é único

(Joana, excerto de texto entregue na supervisão do estágio básico).

Vinciane Despret, a propósito dos dispositivos experimentais em pesquisa, trata de um problema que muito preocupa as ciências humanas e a Psicologia: "influenciamos aqueles que interrogamos" (Despret, 2011, p. 44), ou seja, as expectativas do pesquisador afetam os resultados de seus estudos com seres humanos. Por muito tempo, acreditou- se em uma certa condescendência dos sujeitos investigados para com as intenções do pesquisador. O que Despret (2011) argumenta é que não são os sujeitos de pesquisa que seriam essencialmente obedientes ao pesquisador, mas sim que o próprio dispositivo das pesquisas, o modo como, por exemplo, as situações experimentais são estruturadas é que produzem essa obediência.

Inspirados pela discussão feita por Despret (2011), diríamos, ao modo de uma analogia, que não temos considerado, na análise das intervenções psi, o plano do dispositivo, dos fazeres concretos que produzirão uma coisa ou outra. Talvez porque insistamos nessa transposição direta de domínios do conhecimento que não coincidem, ao afirmar que a teoria é a técnica do psicólogo. Acostumados a pensar segundo a teoria do espectador do conhecimento, supomos que nossa visão de homem e de mundo, as nossas teorias, afetariam diretamente a "prática", ou seja, aquilo que fazemos no plano das intervenções psi. Lembremos que Regina se preocupa com o fato de que nossas opiniões direcionam a prática. Também vimos os estudantes dizerem que o psicólogo é o próprio instrumento de seu trabalho, não havendo mediação alguma entre seu ser e seu método. Pensamos que são essas duas associações que produzem a ideia de que a discussão dos objetivos de determinada prática ou dos pressupostos do psicólogo são mais importantes do que a da técnica. Supõese que os primeiros determinariam a segunda, quase que por um passe de mágica. Daí, talvez, a surpresa e a culpa quando vemos que não conseguimos fazer aqui nossas ideias ou quando não sabemos como devolver.

Também nos surpreendemos quando vemos, por exemplo, em um psicanalista, atitudes incoerentes com o que preconiza o método e a ética psicanalíticos. Porque acreditamos que o psicólogo é a sua teoria, isso se torna 
Outra implicação da consideração da linguagem a partir do paradigma da fabricação de utensílios para o campo psi é que não necessariamente intervirei psicanaliticamente, por exemplo, só porque suponho que sou ou porque quero ser psicanalista ou porque uso termos e descrevo meu fazer segundo a psicanálise. um contrassenso. Não sabemos explicar essas situações, às vezes supomos que o psicólogo não entendeu bem a teoria ou que nós não entendemos bem o psicólogo ou a teoria. Em determinado momento de um dos encontros, Jones faz a seguinte observação: "no discurso de muitos professores, parece que eles não entenderam bem a teoria, né (risos) eles falam como se fosse uma doutrina, que todo mundo tem que seguir e a própria teoria não diz isso!".

O que fica implícito nessas situações é que estamos supondo: 1) que a teoria existe realmente em algum lugar objetivo, possivelmente nos textos ou na mente dos autores; 2) que pessoas podem aprender essas teorias reais e incorporá-las em suas atitudes e em suas práticas, quase que por um processo de passagem do conteúdo dos livros ao ser e ao fazer; 3) que os seres das pessoas são estáveis e coerentes e 4) que as teorias assim incorporadas dariam ao seu detentor uma posição privilegiada de conhecimento; uma chave de acesso à realidade mesma. Tudo parece se encaminhar para a ideia de que, entre teoria e prática, haveria um tubo em que textos passassem a corpos e vice-versa.

Utilizamos a palavra tubo em referência ao trabalho de Michael Reddy (1979) no campo da linguagem. $O$ autor percebeu na língua inglesa dezenas de expressões que denotavam que as palavras são tomadas como tubos a partir dos quais as ideias circulam de mente em mente, como se os sentidos e significados residissem nas palavras em si. Assim, se conseguimos encontrar a justa palavra, nosso interlocutor não teria dúvidas sobre nossas ideias. Esse modo de uso da língua leva a crer que a metáfora do tubo seria um bom modelo explicativo da comunicação. $\mathrm{Ou}$ seja, que o problema da comunicação e, consequentemente, do entendimento, seria o da escolha dos tubos corretos.
Contudo, o autor parte da ideia de que conversamos porque não nos entendemos. Desse modo, as palavras não são rótulos ou embalagens de ideias, mas utensílios fabricados e trocados. Ao operar com eles em nosso viver, vamos inventando seu sentido operativo e os oferecendo às pessoas com quem interagimos. Embora nosso interlocutor sempre faça pequenas modificações ao apropriar-se desse utensílio em sua vida, vamos construindo com ele congruências operacionais, que fazem supor que temos o mesmo entendimento. De tal modo que um bom modelo explicativo da comunicação seria o que o autor denominou como o paradigma da fabricação de utensílios. A metáfora dos fabricantes de utensílios dialoga com a teoria do conhecimento de Maturana e Varela (2001), segundo a qual não trocamos signos, mas sim nos tornamos mais congruentes com os domínios cognitivos e as ecologias em que convivemos. Com essa perspectiva, pode-se dizer que os jovens em formação iriam forjando congruências operacionais com a universidade, bem como com os campos de estágios e práticas profissionais e outros de sua vida.

Outra implicação da consideração da linguagem a partir do paradigma da fabricação de utensílios para o campo psi é que não necessariamente intervirei psicanaliticamente, por exemplo, só porque suponho que sou ou porque quero ser psicanalista ou porque uso termos e descrevo meu fazer segundo a psicanálise. Mas sim, porque crio congruências operacionais nesse domínio. Trata-se, antes, de uma modificação estrutural na convivência (Maturana, 2001). Do mesmo modo, não será diretamente que as opiniões do psicólogo direcionarão sua prática. Entre as intenções teóricas, as ideias do psicólogo, e uma dada situação concreta de intervenção, há a mediação dos 
dispositivos, há, sim, um nível técnico, que não tem sido representado nas discussões sobre o conhecer e o conhecimento psi, preocupados que estamos com os princípios, os pressupostos e as teorias. Se nos preocupássemos em descrevê-lo, talvez qualificássemos a colocação do problema das nossas opiniões que direcionam a prática. Contudo, como apontou Joana, a universidade, pelo menos a UFRGS, nem sempre está orientada para o tema dos métodos e técnicas de trabalho. Na supervisão acadêmica, os referidos supervisores de estágio básico perguntaram: das aprendizagens no curso de Psicologia, que ferramentas conceituais te foram úteis para intervir e operar transformações na realidade apresentada pelo campo de estágio? E que transformações a realidade do campo de estágio operou sobre as aprendizagens do curso e nas ferramentas conceituais em uso? Essa pergunta é muito potente, porque situa os conceitos como ferramentas, ou seja, enquanto algo para ser usado e transformado em seu uso. Contudo, se poderia interrogar por que as ferramentas conceituais estão associadas, no modo como as questões são colocadas, apenas à universidade e não aos estágios?

Parece-nos que a universidade tem forçado uma relação do fazer nas intervenções psi com o fazer teórico que, por vezes, não se sustenta. Primeiro, porque supõe que as aprendizagens da universidade são conceituais e, como vimos anteriormente a propósito da discussão sobre as tecnologias da inteligência e ecologias cognitivas, elas extrapolam esse nível. Em segundo lugar, exige que os estudantes descrevam suas práticas segundo as teorias, quando, talvez, não foram somente elas que Ihes ajudaram no trabalho.

Essa é uma questão bastante contemporânea para a formação, pois se vive um momento histórico de reorientação da mesma no sentido do desenvolvimento de competências e habilidades, segundo as Diretrizes Curriculares Nacionais para os cursos de graduação em Psicologia (MEC, 2004). Joana está fazendo o estágio básico, portanto, cursa o currículo pós-Reforma Curricular, que, na UFRGS, teve seu início em 2007. Entretanto, suas considerações apontam ainda para a presença um ensino marcado pelos conteúdos teóricos. Talvez caiba salientar que, aqui também, não haveria um tubo entre a teoria curricular e o currículo vivido na graduação: a Reforma não necessariamente ou diretamente produzirá novas práticas de formação. Mas não se pode deixar de notar que alguns dispositivos curriculares foram transformados e isso tem efeitos na experiência dessa nova geração de estudantes.

Na UFRGS, talvez o principal tenha sido a constituição de um núcleo básico que incluísse disciplinas dos três departamentos desde o início do curso. Antes, eles vinham em blocos: nos primeiros anos, quase todas as disciplinas eram do Departamento de Psicologia do Desenvolvimento e da Personalidade, no bloco intermediário, do Departamento de Psicologia Social e Institucional e, nos anos finais, do de Psicanálise e Psicopatologia. Sobre essa experiência, nova no Instituto de Psicologia da UFRGS, os estudantes comentam:

Flávio: (...) Tu vai pra uma aula e o professor diz o contrário do que o outro disse. De certa forma, tu não pode confiar que as coisas que são ditas elas são o que são, assim (...) Entre uma ênfase e outra, um ano e outro, é como se tu tivesse ido fazer faculdade em outro lugar: falam outras coisas, outra língua, professores, e a gente também acaba falando, é bizarro. E daí tu fica com essa desconfiança meio basal, assim... Não sei como é em outras formações...

Regina: Acho que as pessoas não têm tanto essa contradição... Mas os departamentos 
dividem a maneira como tu vai conhecer fora... Tu tá atendendo uma família e vai buscar nos pensadores, autores... Percebi que eu não procurava ver o que Lacan, Foucault, Skinner falaram... Eu buscava pensar com a cabeça da psicanálise, do desenvolvimento... Tipo, a minha cabeça departamentalizada. A psicanálise não vai entrar aqui, eu tô trabalhando com social... Não eu, mas a formação categorizou alguns teóricos em algumas ênfases, mas não significa que eles não pudessem falar de alguma coisa que acontece ali, tipo Lacan falar de algo daquela família que tá num contexto típico de social.

Jones: Acho que é algo da formação do psicólogo. Trabalhei com colegas de outras universidades nos estágios e vi que eles também têm isso de serem críticos e reflexivos, acho que é da psico. Pela diversidade teórica, faz tu ter uma certa humildade. Aquilo de ver um professor contrariando o outro faz tu ver que a abrangência da teoria não é total, e faz tu ficar sempre pensando nas coisas. A gente se torna crítico com relação à teoria, vê os limites delas, vê que escolha teórica não vai dar conta de tudo

(Excerto de diálogo realizado no último encontro da pesquisa, que reuniu os grupos 1 e 2, após três meses da realização do quarto encontro em cada grupo).

Em nossa experiência de formação nessa universidade (todos os três autores foram alunos da instituição em diferentes épocas, mas todas anteriores à reforma), com os departamentos em blocos, deparar-se com um professor contrariando o outro levava a que escolhêssemos rapidamente um dos lados. Já na experiência dos estudantes pesquisados, que convivem com disciplinas dos três departamentos desde o início do curso, isso parece ter um interessante efeito de demonstrar como as teorias não são verdades últimas que dariam conta de tudo. Contudo, vemos restos dessa ânsia por certezas quando o efeito que essa formação provoca é uma "desconfiança meio basal". Ao invés de uma certeza basal, uma desconfiança.
Regina ainda aponta um efeito "departamentalizador" das ênfases, algo que foi trazido muitas vezes pelos estudantes: se o aluno está fazendo a ênfase de social, parece que só pode usar teorias e conhecimentos dessa área. No curso, ênfases e departamentos se confundem, são elas: Desenvolvimento Humano: Avaliação, Prevenção e Intervenção; Processos Clínicos; Psicanálise e Psicopatologia; Psicologia Social e Políticas Públicas, cada uma pertencente a um departamento.

Vemos, também, na fala de Regina, que a departamentalização do Instituto gera na experiência dos estudantes um efeito de totalização ainda maior do que aquela relativa ao pensamento de cada autor, pois suas diferenças parecem ser reduzidas a uma mesma coerência explicativa, a do departamento, daí se pensar que a cada um deles corresponderia uma epistemologia. É interessante, ainda, que, mesmo questionando as teorias, é nos autores que Regina busca soluções para os problemas que se colocam nos estágios.

De certo modo, o diálogo dos estudantes aponta que ainda se trata as teorias como "teóricas", no sentido idealista do termo. Tratá-las assim pode levar a esse relativismo que se esboça em seu discurso. Daí nossa aposta no reconhecimento do know how em jogo tanto no estudar/teorizar quanto no trabalhar em Psicologia.

Caberia perguntar se as novas diretrizes curriculares reconhecem ou não essa dimensão, ao proporem o modelo das competências e habilidades. Segundo Bernardes (2004, citado por Rivero, 2011), a noção de competência, tal como aparece na Lei de Diretrizes e Bases da Educação Nacional, ainda guarda uma relação com o 
cognitivismo clássico, o qual, como vimos, é bastante diferente das concepções de Maturana, Varela e Lévy. Entretanto, parecenos que tal redirecionamento da formação poderia, sim, contribuir para se descentrar da teoria a colocação do problema do conhecer e do conhecimento psi. Porém, o mais importante, sobre essa discussão, é o que aponta Rivero (2011):

Este aproveitamento dos termos nas diretrizes curriculares acontece independente das variações e polissemia que apresentam dentro e fora dos limites disciplinares da Psicologia, o que sugere que a fidedignidade conceitual é menos importante que a função que o conceito tem como instrumento de governo. Inclusive, nas oportunidades em que a Psicologia utiliza o conhecimento produzido em seu campo sobre competências e habilidades para entender a proposta das diretrizes, surgem indícios de que este documento não se posiciona sobre as diferenças com que os termos competências e habilidades têm sido tratados pelas diferentes linhas de estudo e investigação ( p. 114)

O autor desloca, portanto, do conceito o problema das competências e habilidades. Preocupa-lhe mais o modo obediente como as diretrizes têm sido adotadas nos Projetos Político Pedagógicos investigados em seu estudo. Ao invés de suscitar controvérsias, a Reforma Curricular é reduzida a uma obediência às diretrizes, que foram pensadas de modo relativamente aberto, justamente para que coubessem as singularidades de cada curso em sua realização. Mas, para isso, é importante um trabalho de apropriação a ser feito pelas universidades, que iria além de uma simples imitação.

É interessante que nossa pergunta, na pesquisa, pelo "saber como" da formação psi nem sempre foi compreendida pelos estudantes, podendo denotar como esse nível ainda fica invisível nos espaços de formação, mesmo em um currículo organizado por competências. Mas, a partir dessa pergunta, obtivemos descrições do fazer psi que consideramos muito mais ricas do que se apenas perguntássemos pelas ferramentas conceituais utilizadas em suas práticas:

realizo um grupo com agentes comunitárias no meu estágio. (...) Tenho pensado nessa intervenção a partir dos seus objetivos. Pelo o que escutei das agentes, acredito que é preciso trabalhar sua capacidade de comunicação (dentro e para fora do grupo), sua auto-estima e sua identidade profissional, para que elas possam se colocar diante da chefia e do restante da equipe.

Contudo, não sei dizer se os três encontros que tivemos até aqui conduziram as agentes nesse sentido. O que, afinal, um psicólogo (ou estudante de Psicologia) pode fazer pelas pessoas? Ainda não está claro para mim o alcance das nossas intervenções. De certa forma, acaba sendo um aprendizado planejar intervenções e objetivos, e outro, confrontar-se com o que acontece a partir dos nossos planos, sabendo não esperar que eles se cumpram.

Isso parece um pouco com a dicotomia teoria e prática, da qual a nossa formação parece não dar conta a não ser nos estágios, me deixando com a impressão de que as aulas pareceram uma introdução incipiente, muitas vezes desnecessária, à prática. Por outro lado, apesar de ter essa impressão, acredito que o que vi em teoria deve ter penetração na minha prática sem que eu perceba.

Para o último encontro que tive com as agentes, planejei uma dinâmica para que discutíssemos a sua relação com as supervisoras, que são da própria unidade, uma enfermeira e uma assistente social. (...) Penso nas dinâmicas como forma de oportunizar que todas se coloquem, que se escutem, e que possam ter um ponto de partida para expressar suas questões acerca do tema sugerido por elas mesmas para discussão.

A dinâmica foi a seguinte: cada uma delas usaria o corpo de uma das colegas para fazer uma escultura, cujo tema seria "como me sinto em relação à supervisão". Cada uma explicaria o porque da sua escultura. Tirei isso da minha experiência com o teatro e, para ser sincero, não sei que pensaram as agentes da minha ideia. Quis avaliar a dinâmica com elas, mas a discussão foi 
tanta que nem houve tempo. O que percebi foi um constrangimento inicial, que foi aos poucos vencido, fazendo emergir algumas coisas nas esculturas. Não sei, contudo, se o mesmo conteúdo não podia surgir a partir das falas livres, já que não vi nenhuma grande novidade em relação ao que já tinha escutado das agentes. Será que eu que não soube explorar melhor a dinâmica? Talvez. E isso é uma coisa interessante da experiência: elas traz nuances pras nossas ideias. Se pensa uma coisa, mas quando se executa, é outra, muito mais complexa e rica. Eu não havia pensado, por exemplo, se todas as ACS apresentariam suas esculturas e depois discutiríamos as semelhanças e diferenças, ou iríamos discutindo ao longo das apresentações. Acabamos fazendo dessa última forma e senti que nem a dinâmica, nem a discussão, conseguiram fluir naturalmente até que terminássemos as esculturas. Era uma nuance que eu não tinha pensado na condução do processo, mas que talvez tenha sido decisiva no alcance da atividade proposta.

Me parece que, nesse sentido, adoto uma prática de pesquisa constante ao longo dos estágios. Tomo aqui como pesquisa a disposição de estar atento à experiência para aprender (talvez o que não se aprenda nas aulas). Contudo, acho que ainda vivemos uma primazia acadêmica da teoria sobre a prática, o que gera certas expectativas de que o estágio seja o momento em que vamos colocar em prática aquilo que já aprendemos.

Acredito que seja por isso que me senti estranho ao sugerir algo que a princípio não é "da área" (dinâmica baseada em jogo teatral), como se "fazer uma experiência" fosse algo arriscado e não recomendável. Para escolher a tal dinâmica, usei algo que chamaria de feeling, sensibilidade, enfim, e talvez alguma ideia de desenvolvimento dos sujeitos que envolva a necessidade de se criar laços (da minha experiência em oficinas, e nos livros, jogos teatrais como o utilizado geram intimidade e expressividade, mas isso se exercitados sistematicamente) e a conveniência de partir de registros corporais porque esses são primários em relação à fala. Esses são pressupostos que parecem passar pela psicanálise, pelas teorias do desenvolvimento, pela Psicologia social, enfim, não sei bem de onde os tirei, mas eles circulam pela minha cabeça.

Parece-me agora que o teatro foi um espaço de formação psi para mim, porque de certa forma atravessou a minha prática no estágio. O curioso disso é que as oficinas e ensaios teatrais estão mais presentes para mim do que os grupos "psi" de que participei, que foram poucos. Contudo, custo a legitimar o exercício do teatro como intervenção psi porque este está distante do mundo da teoria psicológica. Ou melhor, eu não conheço bem ainda as conexões teóricas que sei que existem entre uma coisa e outra. Conhecer a teoria, contudo, não garante a intervenção. E por aí vamos... (Flávio, escrito produzido no percurso da pesquisa sobre seu fazer) [grifos nossos].

Parece-nos que essa descrição aberta e em primeira pessoa colocou melhor o problema da relação teoria e prática na Psicologia do que se perguntássemos: como você vê a relação teoria e prática no seu estágio? O depoimento abre para muitas questões, mas gostaríamos de destacar que ele insere teoria e prática, pensar e agir em uma circularidade e, sobretudo, inclui o corpo, a experiência, a contingência e a experimentação na descrição do que é fazer Psicologia.

Um olhar atento para o fazer concreto e incorporado do psicólogo torna explícito que esse profissional e suas práticas nunca estiveram reduzidos apenas às suas teorias. Tratar o fazer psi como teórico é desconsiderar que o conhecimento se dá em uma ecologia cognitiva, que o chamado "conhecimento tácito" é importantíssimo e que querer explicar o ser e o fazer de um psicólogo, até mesmo sua ética, por uma teoria, é operar uma purificação. Isso sim, esse modo de consideração da teoria, é tomar o trabalho real pelo prescrito e o tácito pelo conhecimento legitimado pelos espaços acadêmicos de formação. 


\section{Etiane Araldi}

Mestre em Psicologia Social e Institucional pela Universidade Federal do Rio Grande do Sul, Porto Alegre RS - Brasil.

E-mail: eti_ane@yahoo.com.br

\section{Cleci Maraschin}

Doutora em Educação pela Universidade Federal do Rio Grande do Sul. Docente no Departamento de Psicologia Social e Institucional da Universidade Federal do Rio Grande do Sul, Porto Alegre - RS - Brasil.

E-mail: cleci.maraschin@gmail.com

\section{Rafael Diehl}

Doutor em Informática na Educação pela Universidade Federal do Rio Grande do Sul. Docente no Departamento de Psicologia da Universidade Federal de Pernambuco, Recife - PE - Brasil.

E-mail: rafadiehlbr@gmail.com

Endereço para envio de correspondência:

SQN 405 bloco B, ap 305.CEP: 70846-020 - Brasília,DF

Recebido 30/01/2013, Aprovado 29/08/2013.

\section{Referências}

Caliman, L. V., \& Almeida, R. G.. (2009). Entrevista com lan Hacking (por Paul Kennedy e david Cayley). Psicologia \& Sociedade, 21(3), 465-470. doi: http://dx.doi.org/10.1590/ S0102-71822009000300021

Certeau, M. D. (1994). A invenção do Cotidiano: 1. Artes do fazer (E. F. Alves, Trad.). Petrópolis, RJ: Vozes

Depraz, N., Varela, F., \& Vermersch, P. (2003). On becoming aware. Amsterdam: John Benjamins.

Despret, V. (2011, jan./abr.). Os dispositivos experimentais. Fractal: Revista de Psicologia, Niterói, 23(1), 43-58,

Dewey, J. (1929). The quest for certainty: a study of the relation of knowledge and action. New York: Minton, Balch \& Company.

Dupuy, J. P. (1996). Nas origens das ciências cognitivas. São Paulo: Unesp.

Ferreira, A. A. L. (2007). O surgimento múltiplo da psicologia. In A. M. Jacó-Vilela, A. A. L. Ferreira \& F. Portugal (Orgs.), História da Psicologia: rumos e percursos (pp.13-46). Rio de Janeiro: Nau.

Kastrup, V. (1999). A invenção de si e do mundo: uma introdução do tempo e do coletivo no estudo da cognição. Campinas,SP: Papirus.

Latour, B. (1994). Jamais fomos modernos. Rio de Janeiro: 34

Lévy, P. (1993). As tecnologias da inteligência. Rio de Janeiro: 34.

Maraschin, C. (2004). Pesquisar e intervir. Psicologia \& Sociedade, 16(1), 98-107. doi: http://dx.doi.org/10.1590/S010271822004000100008
Maturana, H. (1999). A ontologia da realidade. Belo Horizonte: Ed. UFMG.

Maturana, H. (2001). Cognição, ciência e vida cotidiana. Belo Horizonte: Ed. UFMG.

Maturana, H., \& Varela, F. (2001). A árvore do conhecimento. São Paulo: Palas Athena.

MEC, Conselho Nacional de Educação (2004). Resolução CNE/CES n $n^{\circ} 8$ de 7 de maio de 2004. Institui as Diretrizes Curriculares Nacionais para os cursos de graduação em Psicologia. Brasília, DF: Autor.

Reddy, M. (1979). The Conduit Metaphor: A case of frame conflict in our language about language. In Ortony, A. Metaphor and Thought (pp.164-201). Cambridge: Cambridge University Press.

Rivero, N. E. E. (2011). Formação em psicologia e governamentalidade. Tese de Doutorado, Faculdade de Psicologia, Pontifícia Universidade Católica do Rio Grande do Sul, Porto Alegre.

Rocha, M.L., \& Aguiar, K.F. (2003). Pesquisa-intervenção e a produção de novas análises. Psicologia: Ciência e Profissão, 23(4), 64-73. doi: http://dx.doi.org/10.1590/S141498932003000400010

Varela, F. J. \& Shear, J. (1999) The view from within. Journal of Consciousness Studies 6(2/3), 293-96

Varela, F. (1996). Quel savoir pour l'étique? Paris: La Découverte.

Varela, F., Thompson, E., \& Rosch, E. (2003). A mente incorporada: ciências cognitivas e experiência humana. Porto Alegre: Artmed. 